\title{
PUBLIC EXPECTATIONS OF THE RECOVERY AND REHABILITATION PLAN OF POST- HAIYAN IN A PHILIPPINE MUNICIPALITY
}

\author{
Ara Joy Uy Pacoma \\ Social Science Unit, Leyte Normal University, Tacloban City, Philippines \\ (aupacoma@up.edu.ph) \\ DOI: https://doi.org/10.22452/jati.vol25no1.7
}

\begin{abstract}
This study aims to determine the level of expectation of respondents of the Rehabilitation and Recovery Plan (RRP) of post-Haiyan in a Philippine Municipality. The data obtained from households in the 12 barangays of Balangkayan, Eastern Samar, Philippines. Household members surveyed to determine the level of expectation and perception of respondents on the implementation of the rehabilitation and recovery plan in their municipality. Results reveal that age, stakeholder type, and educational attainment of citizens affect public expectations on the RRP implementation. The results of this study can help local government units to incorporate an interactive planning/implementation process into their policy-making process to lessen the gap or mismatch of expectations between the local officials, residents, and other stakeholders such as NGOs/humanitarian organisations.
\end{abstract}

Keywords: politics, public expectations, post-Haiyan, recovery and rehabilitation plan, Philippines

\section{Introduction}

The Philippines is vulnerable to hazards like typhoons, earthquakes, landslides, and volcanic eruptions. It even ranks as the third most disaster-prone country in the world (Global Nation Inquirer, 2012). The country has experienced the world's strongest typhoon, super typhoon Yolanda, internationally named as Haiyan, on November 13, 2013, with maximum sustained winds of $235 \mathrm{kph}$ and gustiness of up to $275 \mathrm{kph}$ (Philippine Atmospheric Geophysical and Astronomical Services Administration [PAGASA], 2013). Consequently, it has 
recently hit by earthquakes ranging from magnitude 4.6 to magnitude 6.5 (Philippine Institute of Volcanology and Seismology, 2017). These kinds of disasters have left a path of devastation that destroyed many infrastructures and took many lives.

This fact pushes the government, especially the local government units, to make its disaster response and its rehabilitation and recovery efforts more effective and citizenry-based. Cognizant of the expectations of the public that may arise from the implementation of particular plans, local officials will be able to manage such hopes for a more efficient and improved rehabilitation and recovery plans.

As central as it is to democratic political processes, public expectations have been used as a yardstick to measure the success or failure of plans and programs such as rehabilitation and recovery plans of governments. Public expectations have also used to stimulate interest and demand for government plans/ programs or induce cynicism and disillusionment towards such. However, despite the wealth of studies focusing on the concept of politics of public expectation, few scholars have dealt with circumstances emphasising on public expectations that are not lifted by political rhetoric, soaring promises, publications, promotions, consultations and information drives. There is limited literature dealing with the indicators of expectation gaps, cloud, or vacuum, which is very important in determining where such occurred, as well as in deciding accountable individuals for such phenomena. Notably, understanding and managing expectations are vital in democratic political processes. If expectations are adequately understood and operated, the public may be interested in engaging and participate more in essential decision-making processes that ultimately affect them.

Balangkayan is a municipality in Eastern Samar, the Philippines which is significantly vulnerable to natural hazards, especially typhoons because of its geographical location. Hence, it is crucial to identify the gaps in the implementation of the Recovery and Rehabilitation Plan (RRP) to make it more useful for the people.

The study aims to determine the level of expectations of the respondents on the implementation of the rehabilitation and recovery plan in Balangkayan, Eastern Samar. This study would like to answer the following questions: What is the profile of the respondents in terms of age, sex, educational background, and type of rehabilitation and recovery projects availed? What is the respondent's level of expectation on post-Haiyan RRP in their municipality? Is there a significant difference in the respondent's level of expectations according to the profile variable? 


\section{Theoretical Background}

This research grounded on an amalgam of two existing theories regarding public expectations and the indicators of political disengagement. The former refers to the Public Expectations Theory, which provides a framework against which we can analyse the mismatch between expectations and governmental performance or the capacity of the plans made by the government, Initially used as a framework for assessing the expectations revolving around the Responsibility to Protect principle (Gallagher, 2015; Dommett \& Flinders, 2014; Flinders \& Kelso, 2011). Gallagher (2015) posited that the relationship between expectation and capacity contributes to the creation of a yardstick helpful in managing "reasonable" expectations from different actors involved. Secondly, it assists in the assessment of the success/failure of a plan. The expectations should be in match with the capacity of the program itself and of the government's ability to fulfil the project. Expectation gaps, expectation clouds, and expectation vacuums help facilitate expectation management. Political disengagement indicators used to measure the expectations mentioned above. Thus, the former theory complemented with Dempsey and Johnston's (2018) framework on Political Disengagement which presents two indicators, namely: political attitudes and community engagement. Dempsey and Johnston (2018) emphasise the importance of specific negative attitude towards the political system that drives particular forms of political disengagement. They posit that political attitudes towards the plan's impact, efficiency, and success can help measure the level of political disengagement of the public (Dempsey \& Johnston, 2018). Subsequently, community engagement is defined as taking or has taken part in public consultations, contributed to a discussion, and has taken an active role in a campaign. They highlighted that the lesser the number of people engaging in these kinds of political activities means a higher level of political disengagement among such individuals/groups (Dempsey \& Johnston, 2018).

\section{Literature Review}

The review of related literature of this study discusses the different terrains about the formulation as well as the implementation of the rehabilitation and recovery programs and other studies discussing the same matter. It will include the legal and institutional framework of recovery and rehabilitation plans, the accountability pertaining to the formulation, and other international studies regarding the accountability framework. Similarly, this will also include a section on the politics of public expectation with a focus on expectation gaps, expectation vacuums, and expectation clouding. 


\section{Legal and Institutional Framezork}

The State serves as an avenue to extend help with prior importance to those people in need after a disaster. With the policies given by Philippine Disaster Risk Reduction and Management Act of 2010 otherwise known as R.A. No. 10121, the State is also given the full responsibility upon the enactment and success of the provisions under this act. Also, it justifies the emergent need for rehabilitation and recovery plan after a disaster.

Moreover, the Philippine Development Plan (PDP) 2011-2016 ("Philippine Development Plan (PDP) 2011-2016", n.d.) aims to address the socio-economic factors of the country by adopting a framework of inclusive growth that incorporates high-sustained growth, generates mass employment, and reduces poverty. It has become a tool for the government to achieve a rapid and sustainable economic growth and development, improve the quality of life of the Filipinos, empower the poor and the marginalised, and enhance the nation's social cohesion. Thus, the need for PDP arises when typhoon Haiyan hit the affected regions, which further worsen the socio-economic factors of the areas affected.

The aftermath of Yolanda left so much devastation in the affected regions. The Office of Civil Defence saw the need for assessing the impacts of the disaster and prioritising the rehabilitation and recovery plans which resulted in a post-disaster needs assessment on December 2013. Accordingly, based on the Post-Disaster Needs Assessment development process, the Office of Civil Defence engaged the National Government Agencies (NGAs), Local Government Units (LGUs), the Civil Society Organisations (CSOs) and Non-Government Organisations (NGOs), and barangay officials and residents in conducting a post-disaster needs assessment. It covers Damage and Loss Assessment (DaLA) and Human Recovery Need Assessment (HRNA). HRNA includes recovery and reconstruction framework. With the help of these agencies, it further narrows the scope to assess the damage brought by the typhoon to the local level and thus will help better formulate the specific area in the local level that needs an immediate response.

The Presidential Assistant for Rehabilitation and Recovery (PARR) unified the efforts of the government and other agencies involved in the recovery and rehabilitation of Yolanda-affected areas. The established five-cluster of PARR, together with the governors and mayors supported the formulation of programs and plans of the Comprehensive Rehabilitation and Recovery Plan (CRRP). The CRRP establishes guidance for the implementation of departments and agencies addressing the post-disaster needs assessment of the people in provincial and city levels. 


\section{Accountability Emphasised in Policy-Making and Implementation}

Underlying the notion of the policy cycle approach as propounded by Cairney (2011) is the understanding that policymakers divide the process into a series of stages. That is, from identifying the policymakers' aims, selection of policy measure, ensuring the population and the legislature legitimising the selection choice, identifying the necessary resources, implementation, and evaluation of the policy. It's reflected in the three core policy phases in which issues or concerns become priorities for the citizens, private bodies, government officials or politicians that will shape the public agenda. The citizens or their representatives decide the policy choices, the officials and other groups with interest in the policy outcome made and taking the policy into action follows. In essence, the stages are not mere formalities and the actors involved in the policy process play critical roles.

Moreover, Barret and Fudge (1981) build upon the action-centred approach, which defines policy implementation as performance rather than conformance. Furthermore, it speaks of policy implementation as a performance of context-dependent; thus, the perspectives of the actors and the people being affected by the policy outcome must be heard and be taken into consideration (Barret \& Fudge, 1981). In other words, policy implementation is conceived both as a negotiating process as well as a responsive process. Barret (2004) further expounds that policy implementation can no longer conceptualise as a single linear progression of making policy up until taking it into action. It has become a recursive action-and-response process.

Policy-making and implementation emphasise the participation of the citizens in the processes of decision making, policy formulation and implementation. It also stresses accountability and responsiveness of leaders to the governed.

\section{The Politics of Public Expectation}

\section{Expectation Gaps, Expectation Vacuums, and Expectation Clouds}

Public expectations have been a key component in assessing the failure/success of politicians, political processes, political institutions (Dommett \& Flinder, 2014; Flinders \& Kelso, 2011). Similarly, it shapes public opinion and ultimately generates high/low approval ratings of the electoral candidate or policies from the public (Waterman, et al., 2014). But as varied and as vast as it is, concerned authorities such as politicians and government officials must manage public expectations. Positive feedback and hope from the masses rather than cynicism and disinterest to be induced in the campaigns, policies, or programs advanced by such personae (Dommett \& Flinder, 2014; Flinders \& Kelso, 2011; Waterman, 
et al., 2014). Barack Obama, for instance, during his 2008 presidential campaign, was faced with high expectations from the electorate as he promised hope and change through his slogan "Change we can believe in" alongside with the chant "Yes We Can!" But as the campaign geared towards the end, Obama, his advisers and his campaign staff saw the need to lower the public expectation as the USA was facing an economic downturn (Dommett \& Flinders, 2014). In turn, his campaign messages were filled with realistic tones and promised to serve as markers for his administration (Dommett \& Flinders, 2014).

Nevertheless, challenges arise when expectations are not well understood and managed. Unreasonable public expectations might happen when the capacities of policies or programs are not well understood and not adequately disseminated (Gallagher, 2015). The existence of capacity-expectations gaps in any political process makes it hard to create reasonable expectations that will be utilised by the public to assess the success or failure of policy or any political process or political institution that is under scrutiny (Gallagher, 2015; Flinders \& Kelso, 2011)). Consequently, expectation gaps may also rise when politicians lay down many promises during the campaign but fail to keep all, if not none, of the promises given due to lack of capacity and resources, or both (Dommett \& Flinders, 2014). The overpromising of politicians during the campaign may increase public expectation and eventually serve as a tool to measure the success/failure of the politician's administration.

However, there are cases of expectation gaps that can be done deliberately or unintentionally as in the case of expectation clouding and expectation vacuums. Expectation clouding may arise due to the failure of the duty bearers to clearly explain a policy, program, or a plan to the public (Gallagher, 2015). However, expectation clouds also arise because the people are presented with two opposing views about the plan/program. One aspect may come from the advocates of the plan stimulating the interest of the public. At the same time, the other composed of the plan's detractors injecting doubts on the capacity and implications of the plan/program (Dommett \& Flinders, 2014). It gives the public a vague picture of what such policy is about, and eventually, disengage and lose interest in the implementation process. On a different note, expectation vacuum arises when duty bearers fail to stimulate the attention of the public towards a particular plan (Dommett \& Flinders, 2014; Gallagher, 2015). It is likely to produce limited public engagement because the government officials and its partner agencies have failed to induce interest and demand for such plan/program. It is important to note that civic engagement is essential in policy-making processes and implementation. So if citizens are politically 
disengaged, then the role of the people is limited to only audiences in information dissemination drives.

Recent studies in the literature provided little information and explanation on the extent by which public expectations have contributed to the increasing levels of political disengagement or dissatisfaction, notwithstanding research literature on accountability and the politics of public expectations hitherto. There have been few studies focusing on the public expectations vis-àvis accountability which stresses on the importance of the role of the citizens as relevant stakeholders and the significance of expectation management to make plans or policies more effective. Because of the need to examine the implications of public expectation in the implementation of rehabilitation and recovery plans, this study aims to set out further understanding and explore the relationship of public expectations and accountability in the policy implementation process.

\section{Significance of the Study}

Sublevels of government, particularly local government units can strengthen and make their Rehabilitation and Recovery Plans (RRP) more effective through the lessons that will be gained in this study because this research will identify the strengths, weaknesses and gaps in the implementation of the RRP. The research will, likewise, be significant for non-government organisations (NGOs) and civil society organisations (CSOs) implementing and helping LGUs to strengthen the implementation of, and the ways to implement such a plan. The study of public expectations will shed light on the ways the politicians, government officials, NGOs, and CSOs affect expectations and in turn, provide means by which they can maximise the chance of achieving stated objectives in the RRP.

\section{Research Design}

The descriptive quantitative research design used to achieve the objectives of this research because this research design allows for an empirical inquiry to produce statistically reliable data that is generalisable to a larger population (Daniel, 2016). The quantitative research design was, therefore, preferred for this study to meet public expectation in the implementation of the Balangkayan Local RRP and, as well, to gain greater confidence in the conclusions generated by quantitative surveys.

More precisely, this study used a survey among the residents of Balangkayan as beneficiaries of the Local RRP. The research employed such method because the study involves a statistical treatment in measuring public expectation that is, whether expectation gap/cloud/vacuum in the 
implementation of the Local RRP occurs through the indicators of political disengagement.

\section{Research Locale}

In this study, the research locale was Balangkayan, Eastern Samar, Philippines. The researcher selected this place because it is one of the coastal municipalities in the Philippines, which is vulnerable to disasters apart from the fact that it was much devastated by Typhoon Haiyan.

\section{Research Respondents}

The respondents of this study were the selected residents of Balangkayan, Eastern Samar, Philippines. To get the total number of sample respondents, the researcher utilised the Slovin's Formula below for a margin of error of $5 \%$ :

$$
n=\frac{N}{1+N e^{2}}
$$

Where:

$$
\begin{aligned}
& n=\text { total no. } \text { of sample respondents } \\
& N=\text { population } \\
& e=\text { margin of error }
\end{aligned}
$$

Stratified sampling used to determine individual research respondents from the fifteen (15) barangays of Balangkayan, Eastern Samar. This technique was preferred to represent every part of the population equally. I utilised the simple random sampling (SRS) procedure in identifying respondents from each barangay. The fishbowl method used for this purpose. With a population of 2,452 households, a total of 344 surveys conducted from July-September 2019.

\section{Research Instrument}

This study used a survey questionnaire, and it consisted of the following parts: a demographic profile and respondent's level of expectation on the implementation of the RRP.

\section{Statistical Treatment of Data}

The data gathered was subjected to different statistical tool to answer the research problems.

Through tabulation response of the respondents was categorised according to the specific question asked. Mainly two variables considered in this 
study, namely: respondent profile (age, sex, educational background, type of RRP projects availed) and respondent's level of expectation on RRP. Frequencies and percentages used to determine each variable. The following formulas were employed:

$$
P=\frac{f}{N} \times 100
$$

Where:

$$
\begin{aligned}
& P=\text { percentage of frequency } \\
& f=\text { frequency of items given } \\
& N=\text { no. of cases or total no. of respondents }
\end{aligned}
$$

The formula below used to analyse the weighted mean of each variable:

$$
x^{\prime}=\frac{\sum x}{n}
$$

Where:

$$
\begin{aligned}
& n=\text { total no. of respondents } \\
& f=\text { frequency } \\
& x^{z}=\text { weighted mean of each item }
\end{aligned}
$$

\section{t-test}

The t-test for independent samples used to determine if there is a significant difference in the expectation from the respondents in the implementation of rehabilitation and recovery plans according to profile variables sex. The t-test utilised at five per cent level of significance, the formula for the t-test presented below (Kanji, 2006).

$$
t=\frac{\left(x_{1}^{\prime}-x_{2}^{\prime}\right)-\left(\mu_{1}-\mu_{2}\right)}{s \sqrt{\left(\frac{1}{n_{1}}+\frac{1}{n_{2}}\right)}}
$$

Where:

$$
s^{2}=\frac{\left(n_{1}-1\right) s_{1}^{2}+\left(n_{2}-1\right) s_{2}^{2}}{n_{1}+n_{2}-2}
$$

\section{Pearson Product-Moment Correlation Coefficient}

To find out if there is a significant relationship between the identified factors, namely: age, educational background and level of expectation on the implementation of Rehabilitation and Recovery Plans. The formula for Pearson $\mathrm{r}$ is given below (Peers, 1996). 


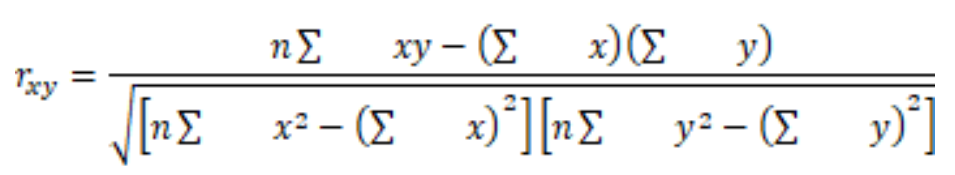

Where:

$$
\begin{array}{ll}
\mathrm{n}=\text { number of paired observations } \\
\sum & x y=\text { the sum of the product of } \mathrm{x} \text { and } \mathrm{y} \\
\sum & x^{2}=\text { the sum of the squared values of } \mathrm{x} \\
\sum & y^{2}=\text { the sum of the squared values of } \mathrm{y} \\
\sum & x=\text { the sum of the values of } \mathrm{x} \\
\Sigma & y=\text { the sum of the values of } \mathrm{y}
\end{array}
$$

\section{Point Biserial}

Correlational matrix tool was used to establish the relationship between the sex and level of expectation on the implementation of Rehabilitation and Recovery Plans. It is a particular case of the Pearson Product-Moment Correlation Coefficient (Linacre, 2008).

$$
r_{\mathrm{pb}}=\frac{x_{1}^{\prime}-x_{0}^{\prime}}{s_{x}} \sqrt{\frac{n_{1} n_{0}}{n(n-1)}}
$$

Where:

$x_{0}^{\prime}=$ mean on the interval or ratio-scale variable of one group

$x_{1}^{\prime}=$ mean on the interval or ratio-scale variable of the other

group

$$
\begin{aligned}
& n_{0}=\text { number of cases in one group } \\
& n_{1}=\text { number of cases in the other group }
\end{aligned}
$$

$s_{x}=$ standard deviation of all measures in the interval or ratio-

scale variable

To test whether the obtained $\mathrm{r}$ is significantly different from zero (specified value of the population correlation coefficient), the following formula of t-test was used:

$$
t=r \sqrt{\frac{n-2}{1-r^{2}}}
$$

Where:

$$
\mathrm{df}=\mathrm{n}-2
$$

To test the null hypothesis, the probability level set at 0.05 level of significance. 


\section{Methods of Scoring and Interpretation}

The data elicited from the questionnaire has recorded using the corresponding quantitative equivalents. Following methods of scoring used:

\section{Stakeholder Type}

The stakeholder type of respondents categorised into three. The corresponding codes are:

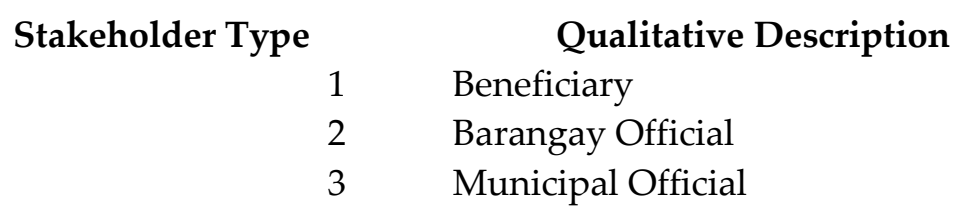

Age. The age of the respondents categorised into three class. The corresponding codes will use:

$$
\begin{aligned}
& \text { Age Range } \\
& \begin{array}{r}
51-\text { above } \\
36-45 \\
18-35
\end{array}
\end{aligned}
$$
Qualitative Description
Adults
Middle Age
Young

Sex. This variable was dichotomised, classified into male and female. The corresponding codes used are:

$\begin{array}{cc}\text { Code } & \text { Category } \\ 1 & \text { Female } \\ 0 & \text { Male }\end{array}$

Educational Background. This variable categorised into six classifications. The corresponding codes used are:

\begin{tabular}{ccl} 
Code & & \multicolumn{1}{c}{ Category } \\
1 & Elementary Level \\
2 & Elementary Graduate \\
3 & High School Level \\
4 & High School Graduate \\
5 & College Level \\
6 & College Graduate
\end{tabular}

Type of Projects Availed. This variable categorised into five categories. The corresponding codes used for this are: 


\begin{tabular}{cll} 
Code & \multicolumn{2}{c}{ Category } \\
1 & Shelter \\
2 & Livelihood \\
3 & Food \\
4 & Household Materials \\
5 & Construction Materials
\end{tabular}

Level of Expectation on the Implementation of RRP

The categorised perception assigned to the following scores are:

\begin{tabular}{|c|c|c|}
\hline Mean Range & Qualitative Description & Interpretation \\
\hline $4.21-5.00$ & Strongly Agree & \multirow{2}{*}{ To a High Extent } \\
\hline $3.21-4.20$ & Agree & To a Moderate Extent \\
\hline $2.61-3.20$ & Neutral & To a Lesser Extent \\
\hline $1.81-2.60$ & Disagree & Not at all \\
\hline $1.00-1.80$ & Strongly disagree & \\
\hline
\end{tabular}

\section{Findings}

\section{Respondent's Profile}

The following results determine the profile of the respondents, that is, their stakeholder type, age, gender, highest educational attainment, and type of projects under the RRP that they have availed.

Table 1: Stakeholder Type

\begin{tabular}{|r|c|c|}
\hline \multicolumn{1}{|c|}{ Variable } & Frequency & Percentage \\
\hline Stakeholder Type & & 89.8 \\
\hline Beneficiary & 307 & 9.9 \\
\hline Barangay Official & 34 & .9 \\
\hline Municipal Official & 3 & $\mathbf{1 0 0}$ \\
\hline Total & $\mathbf{3 4 4}$ & \\
\hline
\end{tabular}

Table 1 shows that 307 respondents, representing $89.8 \%$ of the participating population, are beneficiaries of the Recovery and Rehabilitation Plan of the local government of Balangkayan, Eastern Samar. On the other hand, 34 stakeholders $(9.9 \%)$, are barangay officials, while three respondents $(0.9 \%)$ are municipal officials. It illustrates that the respondents comprised mostly of beneficiaries. The beneficiaries' feedback is proven to improve accountability and the delivery of government programs/plans (World Vision UK, 2016). 
Table 2: Age

\begin{tabular}{|c|c|c|}
\hline Variable & Frequency & Percentage \\
\hline Age & & \\
\hline 18-35 - Young & 116 & 33.7 \\
\hline 36-50- Middle Age & 91 & 26.5 \\
\hline 51 Above - Adult & 137 & 39.8 \\
\hline Total & $\mathbf{3 4 4}$ & $\mathbf{1 0 0}$ \\
\hline
\end{tabular}

As shown in Table 2, 39.8\% of the sampling population are adults, $33.7 \%$ are considered young, and $26.5 \%$ are considered middle-aged. Beneficiaries are comprised of adults as they are shouldering the responsibility of the households as heads (Philippine Statistics Authority, 2019).

Table 3: Sex

\begin{tabular}{|r|c|c|}
\hline \multicolumn{1}{|c|}{ Variable } & Frequency & Percentage \\
\hline Sex & & 62.5 \\
\hline Male & 215 & 37.5 \\
\hline Female & 129 & $\mathbf{1 0 0}$ \\
\hline
\end{tabular}

Table 3 shows that the majority (62.5\%) of the respondents are males. Because of the sampling procedure used, this research data may be consistent with the household heads in Balangkayan, Eastern Samar. One exciting feature in this study is that usually households are headed by the males, only a few households headed by the females (Food and Agriculture Organization and United Nations Development Programme, n.d.).

\section{Table 4: Educational Attainment}

\begin{tabular}{|l|c|c|}
\hline \multicolumn{1}{|c|}{ Variable } & Frequency & Percentage \\
\hline Educational Attainment & & 34.9 \\
\hline Elementary Level & 120 & 12.5 \\
\hline Elementary Graduate & 43 & 19.8 \\
\hline High School Level & 68 & 14.5 \\
\hline High School Graduate & 50 & 9.0 \\
\hline College Level & 31 & 9.3 \\
\hline College Graduate Total & 32 & $\mathbf{1 0 0}$ \\
\hline \multicolumn{2}{r}{$\quad$ 344 } \\
\hline
\end{tabular}


Table 4 portrays that a significant number of respondents $(34.9 \%)$ attained elementary level as their highest educational attainment.

It can be concluded from the table above that, by and large, the respondents were progressive in education. However, they were still far away from higher education which is so important today to create a knowledge-based society (Beltz, 2005).

Table 5: Types of Projects Availed in the Community

\begin{tabular}{|l|c|c|}
\hline \multicolumn{1}{|c|}{ Variable } & Frequency & Percentage \\
\hline Type of Projects availed in the community & 167 & 48.5 \\
\hline Shelter & 177 & 51.5 \\
\hline Livelihood & 310 & 90.1 \\
\hline Food & 139 & 40.4 \\
\hline $\begin{array}{l}\text { Other's (Household Materials: Utensils, Beddings, } \\
\text { Garments, Pail) }\end{array}$ & 58 & 16.8 \\
\hline $\begin{array}{l}\text { Other's (Construction Materials: Coco Lumber, } \\
\text { Yero, Nails, Plywood, Luna, Cement, hollow } \\
\text { blocks) }\end{array}$ & $\mathbf{3 4 4}$ & $\mathbf{1 0 0}$ \\
\hline \multicolumn{1}{|c|}{ Total } & \\
\hline
\end{tabular}

Table 5 illustrates that a majority (90.1\%) of the projects availed by the community is food. While livelihood, shelter, household materials, and construction materials composed $51.5 \%, 48.5 \%, 40.4 \%$, and $16.8 \%$ respectively, of the projects availed by the community. In the immediate aftermath of disasters, food is one of the most basic needs of people and should be secured first (Crutchfield, 2013).

Level of Expectation of the Respondents on the Implementation of the Recovery and Rehabilitation Plan

The following results show the level of expectation of the respondents on the implementation of the Recovery and Rehabilitation Plan (RRP). 
Table 6: Level of Expectation on the Implementation of Rehabilitation and Recovery Plans

\begin{tabular}{|c|c|c|c|}
\hline Statement & Mean & $\begin{array}{l}\text { Qualitative } \\
\text { Description }\end{array}$ & Interpretation \\
\hline \multicolumn{4}{|l|}{ Community Engagement } \\
\hline $\begin{array}{l}\text { 1. The community leaders were involved in the project } \\
\text { planning for RRP in the municipality. }\end{array}$ & 4.00 & Agree & $\begin{array}{c}\text { To a high } \\
\text { extent }\end{array}$ \\
\hline $\begin{array}{l}\text { 2. The community play a vital part in the information } \\
\text { drive about the RRP in the municipality. }\end{array}$ & 3.99 & Agree & $\begin{array}{l}\text { To a high } \\
\text { extent }\end{array}$ \\
\hline $\begin{array}{l}\text { 3. The community leaders were fully aware based on } \\
\text { transparency in the project implementation. }\end{array}$ & 4.08 & Agree & $\begin{array}{l}\text { To a high } \\
\text { extent }\end{array}$ \\
\hline $\begin{array}{l}\text { 4. The community kept posted on the progress of the } \\
\text { project implementation. }\end{array}$ & 3.88 & Agree & $\begin{array}{c}\text { To a high } \\
\text { extent }\end{array}$ \\
\hline Mean & 3.99 & Agree & $\begin{array}{c}\text { To a high } \\
\text { extent }\end{array}$ \\
\hline \multicolumn{4}{|l|}{ Project Impact } \\
\hline $\begin{array}{l}\text { 1. The project improved the wellbeing of the } \\
\text { community. }\end{array}$ & 4.04 & Agree & $\begin{array}{c}\text { To a high } \\
\text { extent }\end{array}$ \\
\hline $\begin{array}{l}\text { 2. The project met the community needs or residents' } \\
\text { requirements. }\end{array}$ & 4.15 & Agree & $\begin{array}{c}\text { To a high } \\
\text { extent }\end{array}$ \\
\hline 3. The residents were satisfied. & 3.71 & Agree & $\begin{array}{c}\text { To a high } \\
\text { extent }\end{array}$ \\
\hline $\begin{array}{l}\text { 4. The residents will love to have more projects from } \\
\text { the project sponsor. }\end{array}$ & 4.38 & $\begin{array}{l}\text { Strongly } \\
\text { Agree }\end{array}$ & $\begin{array}{c}\text { To a high } \\
\text { extent }\end{array}$ \\
\hline Mean & 4.07 & Agree & $\begin{array}{l}\text { To a high } \\
\text { extent }\end{array}$ \\
\hline \multicolumn{4}{|l|}{ Project Efficiency } \\
\hline 1. The project completed on schedule. & 3.41 & Agree & $\begin{array}{c}\text { To a high } \\
\text { extent }\end{array}$ \\
\hline $\begin{array}{l}\text { 2. The project was completed within the budget or } \\
\text { below budget. }\end{array}$ & 3.43 & Agree & $\begin{array}{c}\text { To a high } \\
\text { extent }\end{array}$ \\
\hline $\begin{array}{l}\text { 3. The project had only minor changes based on the } \\
\text { original plan. }\end{array}$ & 3.58 & Agree & $\begin{array}{c}\text { To a high } \\
\text { extent }\end{array}$ \\
\hline 4. The project was efficient to the community needs. & 3.95 & Agree & $\begin{array}{c}\text { To a high } \\
\text { extent }\end{array}$ \\
\hline Mean & 3.59 & Agree & $\begin{array}{c}\text { To a high } \\
\text { extent }\end{array}$ \\
\hline \multicolumn{4}{|l|}{ Project Success } \\
\hline 1. The community wanted to avail of the projects. & 4.40 & $\begin{array}{l}\text { Strongly } \\
\text { Agree }\end{array}$ & $\begin{array}{c}\text { To a high } \\
\text { extent }\end{array}$ \\
\hline $\begin{array}{l}\text { 2. The community beneficiaries were highly loyal to } \\
\text { the projects. }\end{array}$ & 3.88 & Agree & $\begin{array}{c}\text { To a high } \\
\text { extent }\end{array}$ \\
\hline $\begin{array}{l}\text { 3. The project contributed to community economic } \\
\text { value. }\end{array}$ & 4.02 & Agree & $\begin{array}{c}\text { To a high } \\
\text { extent }\end{array}$ \\
\hline 4. $\quad$ The project was a great success. & 3.89 & Agree & $\begin{array}{c}\text { To a high } \\
\text { extent }\end{array}$ \\
\hline Mean & 4.05 & Agree & $\begin{array}{l}\text { To a high } \\
\text { extent }\end{array}$ \\
\hline
\end{tabular}


The dependent variable is the respondent's level of expectation recorded on the survey instrument for the statements that categorised under community engagement, project impact, project efficiency, and project success. Within the study, community engagement had a mean of 3.99; project impact had an average of 4.07; project efficiency had an average of 3.59, and project success had an average of 4.05 .

The interpretation of these data shows that there is a high level of expectation among the respondents on the implementation of the RRP in terms of community engagement, project impact, project efficiency, and project success.

\section{Significant Difference in the Level of Expectation of the Respondents in the Implementation of the RRP as per Profile Variables}

The following results pertain to the significant difference, if any, on the level of expectation of the respondents in the implementation of the RRP according to profile variables namely: sex, age, educational attainment, and stakeholder type. The following discussions aim to determine if the two groups', that is, level of expectation and a particular profile variable, mean showed evidence of a real difference (one that that was unlikely to be due to chance alone). Dempsey and Johnston's (2018) supported that the emphasising indicators such as age, sex, educational attainment, and stakeholder type to affect the level of expectation of a respondent in terms of the implementation of government plans/programs.

Table 7: Statistical Difference Between Respondent's Level of Expectation in Terms of Community Engagement According to Sex

\begin{tabular}{|l|l|l|l|c|}
\hline Variable & \multicolumn{1}{|c|}{$t_{c}$} & \multicolumn{1}{c|}{ Df } & p-value & Interpretation \\
\hline Sex & 1.507 & 340 & 0.133 & $\begin{array}{c}\text { Not } \\
\text { Significant }\end{array}$ \\
\hline
\end{tabular}

Sex. This variable came up with a computed $t_{c}$ value of 0.133 , which is not significant since the $p$-value is higher than alpha which is equal to 0.05 . Hence, the null hypothesis which states, "There is no significant difference in the level of expectation of respondents in the implementation in terms of community engagement in the rehabilitation and recovery plans according to profile variables" failed to reject the 5 per cent level of significance.

The interpretation of these data sets illustrates that there is not sufficient data to suggest that the means of public expectation in terms of community engagement and sex is unlikely due to chance alone. 
Table 8: Respondent's Level of Expectation in Terms of Community Engagement According to Stakeholder Type, Age, and Educational Attainment

\begin{tabular}{|l|c|c|c|}
\hline \multicolumn{1}{|c|}{ Variable } & F & p-value & Interpretation \\
\hline Stakeholder Type & 1.578 & 0.084 & Not Significant \\
\hline Age & 1.801 & 0.037 & Significant \\
\hline Educational Attainment & 1.551 & 0.092 & Not Significant \\
\hline
\end{tabular}

Table 8 shows that no sufficient data is there to suggest that the means of the respondents' expectation in terms of community engagement and stakeholder type and educational attainment was unlikely due to chance alone. However, respondents' expectation and age found to have a statistically significant difference. As shown on the data on the age range of the respondents, the majority $(39.8 \%)$ of the responding population are adults aged 51 years old and above. Hence, the level of expectation of the RRP linked to the age. The older the beneficiary gets, a higher level of expectations come based on the understanding and knowledge of plans. It also implies that community engagement and planning done in collaborative decision making with adult beneficiaries and with the age of members of the community in the implementation of plans for sustainable community welfare and development comes wisdom and experience (Worthy, Gorlick, Pacheco, Schnyer, \& Maddox, 2011).

Table 9: Difference in Level of Expectation of Respondents in the Implementation of RRP in Terms of Project Impact on Sex

\begin{tabular}{|l|c|c|c|l|}
\hline \multicolumn{1}{|c|}{ Variable } & $t_{c}$ & Df & p-value & Interpretation \\
\hline Sex & 1.669 & 340 & 0.096 & Not Significant \\
\hline
\end{tabular}

Sex. This variable came up with a computed $t_{e}$ value of 1.669 , which was not significant since the $\mathrm{p}$-value is higher than alpha which is equal to 0.05 . Hence, the null hypothesis which states, "There is no significant difference in the level of expectation of the respondents in the implementation in terms of project impact in the rehabilitation and recovery plans according to profile variables" failed to reject the 5 per cent level of significance.

The interpretation of these data illustrates that there is not sufficient data to suggest that the means of the respondents' expectation in terms of project impact and sex was unlikely due to chance alone. 
Table 10: Difference in Level of Expectation of the Respondents on the Implementation of the RRP in Terms of Project Impact According to Stakeholder Type, Age, and Educational Attainment

\begin{tabular}{|l|c|c|c|}
\hline \multicolumn{1}{|c|}{ Variable } & F & p-value & Interpretation \\
\hline Stakeholder Type & 1.966 & 0.027 & Significant \\
\hline Age & 1.224 & 0.265 & Not Significant \\
\hline $\begin{array}{l}\text { Educational } \\
\text { Attainment }\end{array}$ & 1.810 & 0.046 & Significant \\
\hline
\end{tabular}

The data in Table 10 depicts the level of public expectation of the RRP in terms of project impact to the stakeholder type and educational attainment, with a pvalue 0.027 and 0.046 , respectively which is significant in RRP implementation in the community. It implies that most of the stakeholders are beneficiaries, with $89.2 \%$ or a total of 305 respondents from the participating population. Most (35.1\% or a total of 120 respondents) of the recipients have elementary-level education. It reveals that the government's social responsibility towards its residents has impacts of the RRP that is felt by beneficiaries of such a plan. It further infers that most of the recipients are of low income and have attained elementary level educational status. These results are consistent with the study of Goodman and Gregg (2010) that a significant contributing factor to patterns of social mobility and poverty are beneficiaries growing up in low-income families, who emerge from school with substantially lower levels of educational attainment.

Table 11: Difference in Level of Expectation of Respondents on the Implementation of the RRP in Terms of Project Efficiency based on sex

\begin{tabular}{|c|c|c|c|l|}
\hline Variable & $t_{c}$ & df & p-value & Interpretation \\
\hline Sex & 0.385 & 340 & 0.701 & Not Significant \\
\hline
\end{tabular}

Sex. This variable came up with a computed $t_{c}$ value of 0.385 , which was e not significant since the $p$-value is higher than alpha which is equal to 0.05 . Hence, the null hypothesis which states that "There is no significant difference in the level of expectation of respondents in implementation of RRP in terms of project efficiency in the rehabilitation and recovery plans according to profile variables" have failed to reject at 5 per cent level of significance. 
The interpretation of these data illustrates that there is no sufficient data to suggest that the means of the respondents' expectation in terms of project efficiency and sex was unlikely due to chance alone.

Table 12: Difference on the Level of Expectation of Respondents on the Implementation of the RRP in Terms of Project Efficiency According to Stakeholder Type, Age, and Educational Attainment

\begin{tabular}{|l|c|c|c|}
\hline \multicolumn{1}{|c|}{ Variable } & F & p-value & Interpretation \\
\hline Stakeholder Type & 1.365 & 0.162 & Not Significant \\
\hline Age & 1.662 & 0.057 & Not Significant \\
\hline Educational Attainment & 1.674 & 0.055 & Not Significant \\
\hline
\end{tabular}

The interpretation of these data illustrates that there is no sufficient data to suggest that the means of the respondents' expectation of the respondents in terms of the project efficiency and stakeholder type, age, and educational attainment was unlikely due to chance alone.

Table 13: Difference in the Level of Expectation of Respondents on the Implementation of RRP in Terms of Project Success based on sex

\begin{tabular}{|c|c|c|c|c|}
\hline \multicolumn{1}{|c|}{ Variable } & $t_{c}$ & df & p-value & Interpretation \\
\hline Sex & 2.338 & 340 & 0.020 & Significant \\
\hline
\end{tabular}

Sex is significant in the level of expectation on the implementation of RRP in terms of project success among other profile variables. Most of the projects require much assistance from male respondents in the community, such as shelter projects which involves carpenters and labourers in building houses and other infrastructures. Recovery and rehabilitation efforts paved the way for construction of shelters, latrines, water systems, village pharmacies, nutrition posts, and barangay health stations (United Nations Development Programme, 2013) that is still male-dominated (Carpenter, 2019).

Table 14: Difference in the Level of Expectation of the Respondents on the Implementation of RRP in Terms of Project Success According to Stakeholder Type, Age, and Educational Attainment 


\begin{tabular}{|l|c|c|c|}
\hline \multicolumn{1}{|c|}{ Variable } & F & p-value & Interpretation \\
\hline Stakeholder Type & 1.163 & 0.306 & Not Significant \\
\hline Age & 1.369 & .172 & Not Significant \\
\hline Educational Attainment & 2.928 & 0.000 & Significant \\
\hline
\end{tabular}

The interpretation of these data illustrates that there is no sufficient data to suggest that the means of the respondents' expectation in terms of project success and stakeholder type and age was unlikely due to chance alone. However, educational attainment affects the level of expectation of respondents on the implementation of RRP in terms of project success. It concurs the study of Beltz (2005) that a knowledge-oriented public will not be easily disengaged and will not lose interest in the implementation process of plans/programs.

\section{Discussion}

The level of expectation of the respondents of the Recovery and Rehabilitation Plan in terms of community engagement, project impact, project efficiency, and project success generally depicted as great extent with an overall mean of 4.05. Finding implies that there is a high level of expectation among the respondents on the implementation of the RRP. However, it is important to note that the means (averages) of particular profile variable and category showed evidence of real difference (one that was unlikely to be due to chance alone). For instance, the difference between the respondents' level of expectation in terms of community engagement and age is statistically significant. It implies that older people are more likely to engage in political and community activities (Dempsey \& Johnston, 2018). Community engagement and planning are usually also done in collaborative decision making with adult beneficiaries or members of the population in the implementation of plans for sustainable community welfare and development (Worthy et al., 2011).

Consequently, the difference between project impact and stakeholder type and educational attainment is statistically significant. It reveals that the government's social responsibility towards its residents impacts the RRP that is felt by beneficiaries of such a plan. It further infers that most of the recipients are of low income and relatively considered weak and have attained elementary level education status (Dempsey \& Johnston, 2018). The difference between sex and educational attainment and project success is also statistically significant. Sex and project success reveal that male beneficiaries create higher levels of expectation on project success as most of the activities required much assistance from male respondents in the community such as in shelter projects (Carpenter, 2019). 
Similarly, a knowledge-oriented public will not be easily disengaged and lose interest in the implementation process of plans/programs (Beltz, 2005). Knowledgeable beneficiaries have higher levels of expectations as they become more critical and hold officials accountable for improper delivery of services rather than being accepting and passive (Dempsey \& Johnston, 2018). Meanwhile, the difference between project efficiency and the profile variables is not statistically significant.

The results of the study are consistent with the public expectations theory which provides a framework against which we can analyse the mismatch between public expectations and governmental performance or the capacity of the plans made by the government (Gallagher, 2015; Dommett \& Flinders, 2014; Flinders \& Kelso, 2011). Similarly, the results are in line with Dempsey and Johnston's (2018) framework for political disengagement. Adults reported higher levels of knowledge about politics, and they are more likely to participate in political activities (Dempsey \& Johnston, 2018). Moreover, people with a low level of educational attainment reported lower levels of political knowledge, satisfaction with democracy, and participation in political activities than people from other educational backgrounds (Dempsey \& Johnston, 2018). Kaufmann and his colleagues (1999) echoed the same idea as there is a strong correlation between accountability and higher levels of socio-economic factors such as income and educational attainment. The government will be perceived as more legitimate if it delivers services in line with people's demands (Jelmin, 2011).

\section{Conclusion and Recommendations}

The level of expectation of the respondents on the implementation of the RRP is affected by age when it comes to community engagement as adults get more engaged in participating in and expecting more on government plans and programs such as the RRP. Stakeholder type and educational attainment influence the project impact as beneficiaries with high educational attainment have felt the higher effect of the RRP more than other stakeholders such as local officials. The level of expectation in terms of the project's success is affected by age, and educational attainment as older generations scrutinise the delivery of services based on their knowledge and understanding of the plan. While respondents with low educational attainment tend to have lower levels of political philosophy thereby being more lenient in measuring the success of the project, these respondents take what is delivered to them regardless of the quality of service delivery. Hence, citizens' participation in the implementation of plans should be emphasised and stimulated by the local government through regular promotions and consultations to give the citizens the perception that 
their opinions matter and that the government is for them, by them, and of them. The Local Government Unit (LGU) should not only bank on and consider adults but also other groups and sectors of the society such as women, youth, and those with low levels of educational attainment among others with regards to participation in planning/implementation processes. More importantly, the LGU should incorporate an interactive planning/implementation process into their policy-making process to lessen the gap or mismatch of expectations between the local officials, residents, and other stakeholders such as NGOs/humanitarian organisations. On a different note, a further study on public expectations vis-avis accountability as influenced by other variables such as personal interests or political inclinations conducted.

\section{References}

Barret, S. (2004). Implementation Studies: Time for a Revival? Personal Reflections on 20 Years of Implementation Studies. Public Administration: An International Quarterly, 82(2), 249-262.

Barret, S., \& Fudge C. (1981). Policy and Action: Essays on the Implementation of Public Policy. London: Methuen \& Co.

Beltz, J. (2005). Mahar, Buddhist, and Dalit: Religious Conversion and Socio-Political Emancipation. New Delhi: Manohar.

Carpenter, J. (2019). Some Industries are still Overwhlemingly Male-dominated: Here's How Women Can Get in. CNN Business. Retrieved from https://edition.cnn.com/2019/03/08/success/women-male-dominatedoccupations/index.html

Crutchfield, M. (2013). Phases of Disaster Recovery: Emergency Response for the Long Term. Reliefweb. Retrieved from https://reliefweb.int/report/world/phases-disaster-recovery-emergencyresponse-long-term

Daniel, E. (2016). The Usefulness of Qualitative and Quantitative Approaches and Methods in Researching Problem-Solving Ability in Science Education Curriculum. Journal of Education and Practice, 7(15), 91-100.

Dempsey, N., \& Johnston, N. (2018). Political Disengagement in the UK: Who is Disengaged? House of Commons Library. Retrieved from http://researchbriefings.files.parliament.uk/documents/CBP-7501/CBP7501.pdf 
Dommett, K., \& Flinders, M. (2014). The Politics and Management of Public Expectations: Gaps, Vacuums, Clouding and the 2012 Mayoral Referenda. British Politics, 9(1), 29-50.

Flinders, M., \& Kelso, A. (2011). Mind the Gap: Political Analysis, Public Expectations and the Parliamentary Decline Thesis. British Journal of Politics and International Relations, 13(2), 249-268.

Food and Agriculture Organization and United Nations Development Programme. (n.d.). Household Structure, Living Standards Incomes and Savings. Food and Agriculture Organization. Retrieved from http://www.fao.org/3/ac685e/ac685e05.htm

Gallagher, A. (2015). The Responsibility to Protect Ten Years on from the World Summit: A Call to Manage Expectations. Global Responsibility to Protect, 7(3-4), 254-274.

Global Nation Inquirer. (2012). Philippines is $3^{\text {rd }}$ Most Disaster Prone Country New Study Shows. Retrieved from http://globalnation.inquirer.net/52858/philippines-is-3rd-most-dsasterprone-country-new-study-shows

Goodman, A., \& Gregg. P. (2010). Poorer Children's Educational Attainment: How Important are Attitudes and Behaviour? Joseph Rowntree Foundation. Retrieved from https://www.jrf.org.uk/sites/default/files/jrf/migrated/files/poorerchildren-education-full.pdf

Jelmin, K. (2011). Democratic Accountability in Service Delivery: A Synthesis of Case Studies. Stockholm: International Institute for Democracy and Electoral Assistance.

Kanji, G. K. (2006). 100 Statistical Tests. London: Sage Publications.

Kaufmann, D., Kraay, A., \& Zoido-Lobatón, P. (1999). Aggregating Governance Indicators (World Bank Policy Research Working Paper No. 2195). Washington, DC: World Bank.

Linacre, J. M. (2008). The Expected Value of a Point-Biserial (or Similar) Correlation. Rasch Measurement Transactions, 22(1), 1154. Retrieved from https://www.rasch.org/rmt/rmt221.pdf

Peers, I. (1996). Statistical Analysis for Education \& Psychology Researchers. London: The Falmer Press.

Philippine Atmospheric Geophysical and Astronomical Services Administration (PAGASA). (2013). Retrieved from http://bagong.pagasa.dost.gov.ph/ Philippine Development Plan 2011-2016 (PDP). (n.d.). Retrieved from http://www.neda.gov.ph/philippine-development-plan-2011-2016/ 
Philippine Disaster Risk Reduction and Management Act of 2010. (2010). Retrieved from http://www.officialgazette.gov.ph/2010/05/27/republicact-no-10121/.

Philippine Institute of Volcanology and Seismology (PHIVOLCS). (2017).

Retrieved from http://www.phivolcs.dost.gov.ph/index.php/news/631primer-on-the-06-july-2017-magnitude-6-5-leyte-earthquake-07-july-

2018\#: :text=At\%204\%3A03\%20PM\%20on,Segment\%20of\%20the\%20Phili ppine\%20Fault/.

Philippine Statistics Authority. (2019). Retrieved from http://psa.gov.ph/sites/default/files/attachments/hsd/specialrelease/cph\% 20202002192020152629.pdf/.

United Nations Development Programme. (2013). Early Recovery and Rehabilitation for Central Mindanao (ERRCM) Project: What is the project about? United Nations Development Programme. Retrieved from http://www.ph.undp.org/content/philippines/en/home/operations/project s/crisis_prevention_and_recovery/project-ERRCM.html

Waterman, R.W, Silva, C. L., \& Jenkins-Smith, H. C. (2014). The Presidential Expectations Gap: Public Attitudes Concerning the Presidency. Michigan: University of Michigan Press. Retrieved from http://www.fulcrum.org/concern/monographs/mp48sd49d/.

World Vision UK. (2016). Using Beneficiary Feedback to Improve Development Programmes: Findings from a Multi-Country Pilot. UK Department for International Development. Retrieved from https://www.intrac.org/resources/using-beneficiary-feedback-improvedevelopment-programmes-findings-multi-country-pilot/

Worthy, D., Gorlick, M., Pacheco, J., Schnyer, D., \& Maddox, W. T. (2011). With Age Comes Wisdom: Decision-Making in Younger and Older Adults. Psychological Science, 22(11), 1375-1380. 